\title{
Nanocarriers for protein and peptide delivery: Recent advances and progress
}

\author{
Samridhi SRIVASTAVA 1 \# (D), Vaibhav SHARMA 1 \# (D), Bharat BHUSHAN ${ }^{2}$, Rishabha MALVIYA ${ }^{3}$, \\ Rajendra AWASTHI 1 * iD, Giriraj T. KULKARNI 1 iD \\ 1 Amity Institute of Pharmacy, Amity University Uttar Pradesh, Sector-125, Noida 201313, Uttar Pradesh, India. \\ 2 Department of Dentistry, Government Medical College, Haldwani, Nainital, Uttarakhand-263139, India. \\ 2 Department of Pharmacy, School of Medical and Allied Sciences, Galgotias University, Plot No. 02, Sector 17-A, \\ Greater Noida, Gautam Buddha Nagar, Uttar Pradesh, India. \\ * Corresponding Author. E-mail: awasthi02@gmail.com (R.A.); Tel. +91-945-923 4530. \\ \# Sharing first authorship in equal contribution.
}

Received: 29 July 2020 / Revised: 01 February 2021 / Accepted: 09 February 2021

\begin{abstract}
Proteins and peptides have been recognized as potential leads for the synthesis of novel therapeutics to treat a variety of human ailments. Unfortunately, therapeutic potential and clinical applications of these biomacromolecules are challenging due to the verge of delivery applications. Nanocarriers offer unique potential to overcome various biological barriers and improve the delivery of therapeutic biomacromolecules like proteins and peptides. A smart nanocarriers-based drug delivery system can be defined as a system that has site-specific drug delivery in a controlled manner against all the physiological barriers and finally metabolized in the body. This review describes various nanocarriers investigated for the delivery of proteins and peptides to augment their clinical applications. Various biological aspects of protein and peptide delivery have been also focused. We also summarized various patents granted for nanocarrier reported to deliver these biomacromolecules followed by a landscape presentation of marketed nano-formulations for protein and peptide delivery.
\end{abstract}

KEYWORDS: Biomacromolecules; nanocarriers; protein delivery; peptide delivery.

\section{INTRODUCTION}

Proteins and peptides are naturally occurring large molecules with secondary and tertiary structures. These macromolecules can effectively control various biological events of the body. Protein and peptide-based therapeutics are attracting the attention of formulation scientist with the breakthroughs in the field of biotechnology. These are highly potent and low toxic due to their target-specific binding properties [1].

Since the synthesis of a first bioactive peptide by Robert Bruce Merrifield in 1953, there is a rapid growth in the development of proteins and peptide drugs. Investigations have been carried out globally in protein and peptide delivery aiming at multiple receptors. Due to the varying pathological and physiological processes, proteins and peptides show beneficial applications to prevent or treat various diseases. Proteins and peptides play a crucial role in the management of various diseases, especially cancer, autoimmune diseases, cardiovascular diseases, and diabetes. Extreme benefits have been achieved through protein and peptide drugs. However, their applications are limited due to the physical and chemical instability caused by enzymatic degradation degraded via enzymes and hydrolysis in the acidic environment in the stomach, rapid elimination from circulation, and low bioavailability [2].

The market for protein and peptide therapeutics is predicted to increase by $10 \%$ of the total pharmaceutical market, which will be the major proportion in the market. Presently a total of 807 peptide drugs are in clinical trials, 197 peptide-based drugs are commercially available in the market and about 100 peptide therapeutics are under the final stage of clinical development. Proteins and peptides have come up as a class of potential therapeutics available in the market [3]. Proteins are part of many receptors and channels in biological membranes that assist in the transport of molecules within the body. Proteins and peptides elicit molecular targeting by involving various biochemical reactions. In the global market, the sale of peptide-based

How to cite this article: Srivastava S, Sharma V, Bhushan B, Malviya R, Awasthi R, Kulkarni GT. Nanocarriers for protein and peptide delivery: Recent advances and progress. J Res Pharm. 2021; 25(2): 99-116. 
remedies was more than 20 Billion US\$ in 2017. It has been predicted that the sale of peptide therapeutics may exceed 60 Billion US\$ by 2026. Continuous growth in the global market of peptide therapeutics is due to the increasing interest of pharmaceutical industries in peptide research to develop multiple peptide drugs. It has been estimated that the oncology segment will continue to dominate the global peptide therapeutics market [3].

Peptide therapeutics are one of the most cost-effective and active market due to its involvement in mass production and investments in the research and development in oncology, autoimmune diseases, rare disease, and genetic disorders. Due to the high cases of lifestyle disorders such as obesity and type II diabetes, United States is on top of the global peptide market followed by the European Union. Asia-Pacific region is foreseen to develop as one of the fastest-growing market of peptide therapeutics by 2024 because of the frightening patient base [3].

The parenteral route is most frequently used for the administration of protein and peptides. Noninvasive routes like nasal, pulmonary, transdermal, etc., have various advantages over the parenteral route which requires frequent injection due to the short in vivo half-life causing poor patient compliance. However, non-invasive routes have restricted delivery of protein and peptide due to their intrinsic physicochemical properties and low permeability across biological membranes [4]. Conventional drug delivery systems have certain limitations such as adverse distribution of drugs all over the body, relatively low site-specific bioavailability, adverse effects, and low accumulation in the target site, etc. [5].

Frequent dose administration is a need to maintain plasma concentration level. To overcome these limitations various chemical modification approaches have been reported [6]. Hence, to overcome these restrictions, absorption of protein and peptide delivery can be increased by delivering through nanostructured delivery carriers. Polymeric nanoparticles also have gained popularity over the other nano-carriers for the delivery of protein and peptides [4]. Peptides can assemble themselves into nanostructures including amphiphilic peptides, linear and cyclic peptides, and a-helical and $\beta$-sheets peptides [7].

During the past two decades, the literature has witnessed great advancement in the development of nano-formulations for site-specific delivery of proteins and peptides with improved therapeutic benefits. Nanocarriers have been used as a strategy to deliver genes and small drug molecules at the target site of interest. Nanocarriers are broadly classified into different types such as liposomes, nanoparticles, dendrimers, nanogels, micelles, carbon nanotubes, metallic and magnetic nanoparticles (Figure 1) [8]. The success of a drug delivery system depends on its ability to transport drugs at the target site. This can be achieved using nanocarriers which are safe and effective delivery vehicles for target-specific drug delivery. These nanocarriers help in site specific delivery of drugs and thus reduces the adverse drug effects, hence, increases the treatment efficacy [5]. Schematic presentation of different types of nanocarrier systems is shown in Figure 1 [8-10].

\section{CHALLENGES IN DELIVERY OF PROTEINS AND PEPTIDES}

Significant efforts have been made in recent years for the conventional delivery of small molecule drugs and similar approaches have been explored for oral delivery of proteins and peptides. However, delivery of proteins and peptides through the oral route has endless challenges for the pharmaceutical scientists to design orally acceptable formulation. The challenging factors include less plasma half-life, enzymatic destruction of proteins and peptides, ion permeability, large molecular size, accumulation of peptide moieties, ability to produce a cell-mediated immune response, and adsorption through cell surface [11]. The physicochemical properties of peptides and proteins make them challenging for exogenous administration, especially via oral administration. The absolute oral bioavailability of proteins and peptides is less than $1 \%$. The barriers to orally administered peptides are solubility, molecular size, intestinal membrane permeability, and hepatic and intestinal metabolism [12]. Mucoadhesion between the mucoadhesive system and mucous layer (i.e. the interaction with mucin fiber) allows the residence time for $4-5 \mathrm{~h}$ in the intestine. This is because of the update time of mucin in the intestinal mucus (50 270 $\mathrm{min}$ ). Transdermal route for protein and peptide delivery faces absorption limitations. Nasal route has limitations such as nasal irritation, a limited amount of drug that can be delivered, rapid renewal of nasal epithelium, acidic $\mathrm{pH}$, endo- and exopeptidases. Buccal delivery of proteins and peptides cause mucosal irritation, low permeability, and bitter taste [13]. 


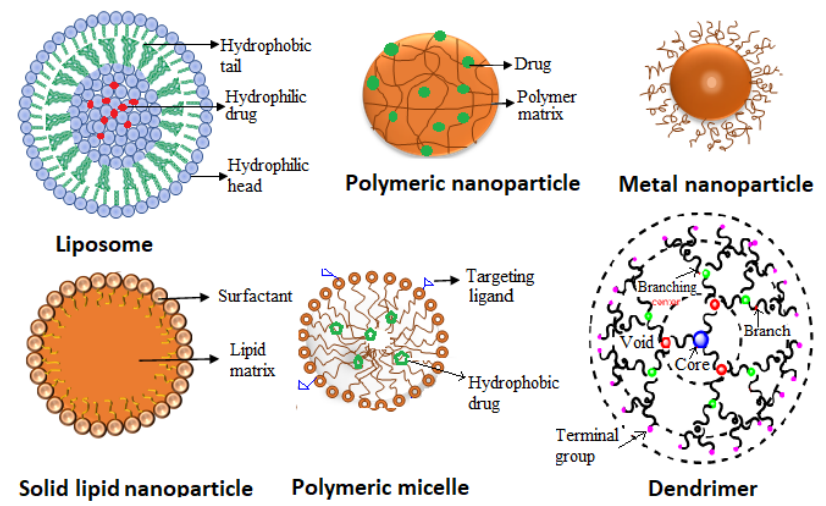

Figure 1. Schematic presentation of different types of nanocarrier systems [8-10].

\section{BIOLOGICAL ASPECTS OF PROTEIN AND PEPTIDE DELIVERY WITH SPECIAL EMPHASIS ON ORAL ADMINISTRATION}

The success of any delivery system depends on its ability to cross the biological barriers, retains its therapeutic efficacy against physiological barriers, and finally metabolized in the body [14]. These properties are determined by the route of administration and target diseased site. After parental administration, tumor stroma, epithelial membranes, the blood-brain barriers, and extracellular matrixes, are common barriers that should be overcome. Parenterally administered bioactive need to be crossed across specific biological barriers depending on the targeted disease. For example, to treat brain disorders the system should penetrate the blood-brain barrier (BBB), which restricts the passage of hydrophilic or large molecules into the cerebrospinal fluid. In case of cancer therapy, the heterogeneous vasculature environment of the tumor site needs to be overcome so that the permeability of drugs can be increased. Impaired lymphatic drainage can increase interstitial fluid pressure in the tumor cells and can become a hurdle for cancer therapy. Epithelium is the common biological barrier for pulmonary and nasally administrated drugs. A topically administered bioactive molecule must cross the skin and mucous. The mucosal membrane of respiratory and gastrointestinal tracts, eyes, vagina, and oral cavity produces a highly viscoelastic and adhesive mucus layer, which acts as a lubricating and protective barrier. Depending on the targeted site, the drug carriers should either quickly permeate the mucus or it must have improved residence time. The residence time can be improved using mucoadhesive materials [15].

Oral route offers several advantages over other routes of administration (rectal, intranasal, buccal, pulmonary, transdermal, ocular). Oral route overcomes the limitations of intravenous route of drug administration such as pain and discomfort. Intravenous injections are used for the delivery of proteins and peptides which cause poor patient compliance and low bioavailability of drug [16]. The visceral mucosal layer provides an extensive large surface area $\left(>300 \mathrm{~m}^{2}\right)$ for the absorption of drugs. Drug molecules trapped by mucus are protected against the plethora of enzymes in the stomach. The intestine has numerous enterocytes that are embedded in the microfold cell covering of Peyer's patches and thus makes it more absorptive. Various gastrointestinal characteristics that limit the delivery of proteins and peptides are presented in Table 1 [17].

Designing a formulation that will be able to pass an acidic environment of the stomach involves different techniques and ideas. The drug should be compatible with dosage form, thus making it more susceptible to consume orally. The dosage form should be able to protect the drug from the enzymatic degradation by pepsin and acidic environment in the stomach. The dosage form should protect the drug from various enzymes present in the intestinal lumen. To facilitate the penetration of dosage form through the intestinal lumen layer, it should possess the aqueous solubility at a $\mathrm{pH}$ range of 6.0 to 7.4 so that it can enter the systemic circulation after passing through the intestinal layer and the basal membrane [16]. Protein and peptide drug delivery deals with three main biological barriers when administered orally, which are intestinal lumen, mucus, and tissues. Each of the three biological barriers prevents the absorption of proteins and peptides due to some or the other obstacles. 


\subsection{Intestinal lumen}

The gastric microenvironment is highly acidic ( $\mathrm{pH}$ of 1.2 under fasting condition). This serves as the first biological barrier for the delivery of proteins. It lowers the affinity of drugs by denaturing or destructing them. Enzymes such as gelatinase and pepsin present in the stomach along with the gastric juices destroy peptide drugs [18]. Proteins and peptides can be loaded with $\mathrm{pH}$-sensitive hydrogels to protect them from the gastric environment. Swelling of anionic hydrogels in the stomach is least. Swelling of $\mathrm{pH}$-sensitive hydrogels protects the bio-actives from the acidic environment of stomach and may allow the drug to release in the intestinal fluid [19]. Hydrogels can also prevent protein and peptide drugs such as insulin against enzymatic degradation from the stomach [20].

Table 1. Properties of various segments of the gastrointestinal tract.

\begin{tabular}{lccccc}
\hline Segment & $\mathbf{p H}$ & $\begin{array}{c}\text { Length } \\
\mathbf{( c m )}\end{array}$ & $\begin{array}{c}\text { Mean } \\
\text { diameter }(\mathbf{c m})\end{array}$ & $\begin{array}{c}\text { Mucus average } \\
\text { thickness }(\boldsymbol{\mu m})\end{array}$ & $\begin{array}{c}\text { Mucus } \\
\text { turnover (h) }\end{array}$ \\
\hline Stomach & $0.8-5$ & 20 & $\mathrm{NA}$ & $245 \pm 200$ & $24-48$ \\
Duodenum & $\sim 7$ & $17-56$ & 4 & 15.5 & $24-48$ \\
Jejunum & $\geq 7$ & $280-1000$ & 2.5 & 15.5 & $24-48$ \\
Ileum & $\geq 7$ & $280-1000$ & 3 & 15.5 & $24-48$ \\
Colon & $7-8$ & $80-313$ & $4-4.8$ & $135 \pm 25$ & $24-48$ \\
\hline
\end{tabular}

Intestinal lumen is composed of a blend of degrading enzymes secreted from the pancreas, such as lipase hydrolyze ester bonds between the fatty acid and glycerol moieties, peptidase hydrolyze peptide bonds, amylase catalyze the hydrolysis of starch molecules into smaller carbohydrate molecules, and trypsin cleaves peptide chains at the carboxyl side of the amino acids. These enzymes are mostly present in the duodenum, and thus, make it more difficult for targeting of drugs to the target organs. They can destroy the nucleic acids. Pancreatic enzymes also act as biological barriers. However, it cannot be considered as a major barrier because of three main reasons: (i) the concentration of enzymes decreases by $90 \%$ along the length towards the intestine from the duodenum to mid-portion of the jejunum, (ii) the $\mathrm{pH}$ of small intestine (lower parts) is higher than the jejunum, and (iii) the short transit time for food in the duodenum does not allow the pancreatic enzymes to degrade drug molecules completely. The delivery of proteins and peptides can be easily prevented by altering the $\mathrm{pKa}$ of formulation [21]. Apart from the enzymatic degradation, the intestinal lumen is susceptible to mechanical damage to drug molecules like protein and peptide moieties by shear stress caused to peristalsis of the gastrointestinal muscles, osmotic sheer stress, and dynamic flow rate of the intestinal fluid [17, 22]. The dynamic flow rate lowers the contact time between the protein/peptide drug and the intestinal layer thus reduces the rate of absorption. Viruses and vaccines are the examples of enveloped biologics which can be easily mechanically damaged in the lumen. Shear stress in the gastric lumen may lead to the apoptosis or cell death. Various research groups are focusing to modulate the structure of hydrogels by incorporating cellulose nanocrystals and polyethylene glycol for improving mechanical properties in terms of shear storage modulus and Young's modulus [23, 24].

\subsection{Mucus}

Mucus is a sticky, viscous, and elastic layer that is lined in the gastrointestinal tract along its length. It serves as the second biological barrier for the delivery of protein and peptide drugs. Mucus functions by entrapping foreign particles, lipophilic moiety reducing their angle of contact with underlying epithelial tissues. Thus, it acts as a part of the immune system by discarding such foreign particles. Chemically, mucus is composed of protein mucin and water. Proteoglycans (glycosaminoglycans covalently attached to the core proteins) binds with water molecules and repel negatively charged molecules. Other components of mucus involved are bacteria, cellular residues, ions, salts, carbohydrate moiety, and antigen killing cells. Mucin is the major part of mucus that is a macromolecule with a size of 0.5-40 mega Dalton linked to each other by disulfide bonds. These mucin macromolecules overlap each other to form a mucosal layer. Glycolipids and glycoproteins are embedded into the inner surface of the mucus layer. Mucus has a dual nature: (i) thicker mucous acts as a biological barrier against the delivery of proteins to the basal membrane, and (ii) thinner mucous act as a diffusing layer for the absorption of orally administered drugs [25].

Mucoadhesion and mucopenetration are the two approaches opted against the oral delivery of protein and peptide (Figure 2). Carrier matrices help in mucopenetrating vehicles orally and it can be controlled by altering its hydrophobicity/hydrophilicity nature. Outer mucus has hydrophobic nature and hence it tends not to interact with hydrophilic materials. To overcome this situation, an increase in electrostatic interactions 


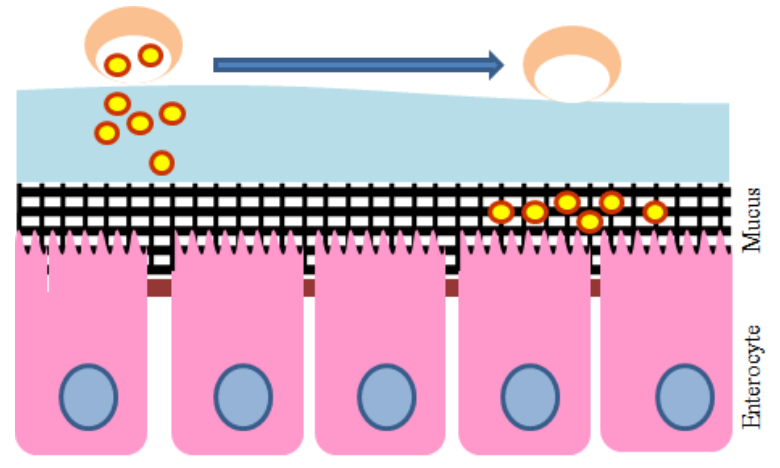

Figure 2. Schematic representation of mucosal layer and the movement of molecules from the outer portion of the mucus to the inner portion.

between the mucus and the carrier moiety led to the transmission of particles [26]. In a study demonstrated by Li et al., Pluronic F127 was incorporated in the liposomal matrix. This helped in inducing the hydrophilicity and removes the electrostatic charge between the particles, thus increased the uptake ability of the liposome and enhanced mucopenetration [27]. Cu and Saltzman reported enhanced mucopenetration of poly(lactic acidco-glycolic acid) nanoparticles coated with poly (ethylene glycol), which nullify the nanoparticle's surface charge [28]. Mucolytic enzymes are also used for the penetration of particles through mucus. Papain, a mucolytic enzyme and polyacrylic acid, is complexed with nanoparticles via physical adsorption. The particles conjugated with enzymes were observed to be capable of reducing mucus viscosity by 5 times and increased oral bioavailability of the proteins and peptides [29].

\subsection{Extracellular barrier (tissues)}

The morphological characteristics of a protein molecule determine its rate of absorption and transport path across the epithelial cells present in the gastrointestinal tract. Absorption of protein and peptide drugs follows two common pathways if consumed orally, namely, transcellular route (transportation across the interior of a cell, i.e. via transcytosis) and paracellular route (diffusion through spaces between two cells). In the transcellular pathway, the protein molecules pass through the epithelial cell surface by entering the enterocytes through the cell membrane of epithelial cells. In the paracellular pathway, small size lipophobic molecules can pass through interspace between the epithelial cells which helps in drug absorption (Figure 3).

Tight junctions between two epithelial cells are the major biological barrier in paracellular pathway. It serves as a major obstacle for orally administered protein and peptide drugs. The transport of orally administered protein or peptide drug depends upon its chemistry, surface properties, hydrophobic/ lipophilic nature of proteins and type of diffusion followed via transport [17]. Molecular density is high on the outer layer of bilayer membrane due to the presence of polar head of lipid molecules, thus makes it less susceptible for the transport of protein and peptide moiety through cell membrane. Even after entering the cytosol of the cell through cell membrane, the hydrolytic enzymes such as lysosome degrade the drug, and reduce its bioavailability [30].

\section{NANOFORMULATIONS AVAILABLE FOR PROTEIN AND PEPTIDE DELIVERY}

Nanostructured materials $(<100 \mathrm{~nm}$ ) are smart drug delivery systems as these can deliver drugs to the site of action at a reduced dose and dosing frequency in a controlled manner. This leads to mitigate the toxicity and/or adverse effects associated with the conventional therapies such as the uncontrollable release of drugs, rapid clearance, nonspecific distribution, and low bioavailability. Stimulus-sensitive nanocarriers are the advanced smart nanocarriers that can undergo structural transitions in response to internal or external stimuli environment changes such as temperature, $\mathrm{pH}$, etc. These smart nanocarriers can also alter the intrinsic complexity of the biological environment and improve the therapeutic benefits of the loaded bioactive. Clinical nanocarriers include liposomes, nanoparticles- gold, iron or silica, polymer-based, or micelle-based formulations. The role of nanocarrier is to increase intestinal absorption into the bloodstream, protect the drug from harsh conditions, target specific site, and controlled release into a target site [31]. However, various challenges associated with the nanocarriers include complexity [2], high production cost [2], scale-up [2], toxicity [32], and formation of by-products during hydrolysis [32]. 


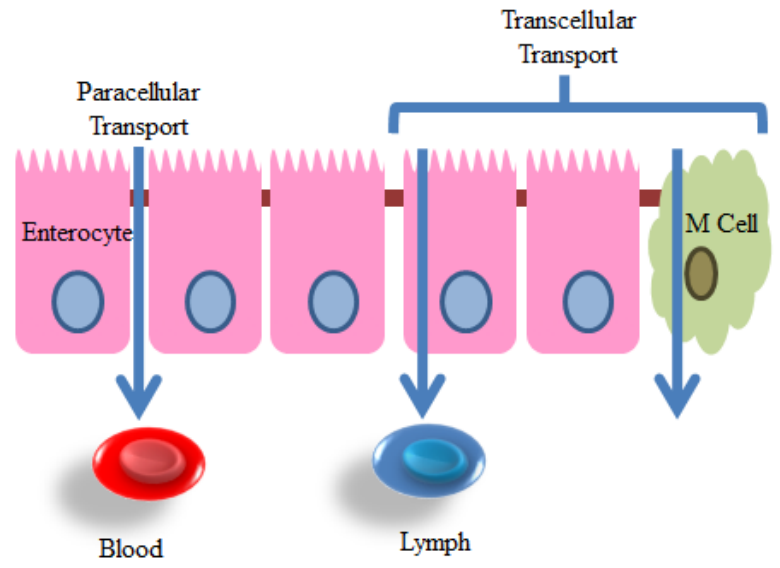

Figure 3. Schematic representation of various routes followed to transport the molecules through mucosal layer.

\subsection{Dendrimers}

Dendrimers serve as carriers for the delivery of bioactive compounds to the target site within the cell to overcome various biological and physical barriers. Various alterations in the physical and chemical behavior of dendrimers have been reported to optimize their interaction with biological moieties such as protein, peptides, gene, and lipid biomembrane. Experimental techniques have elucidated computer simulation for novel dendrimers for better understanding and transmission of protein molecules to the target site.

Investigations have been carried out on dendrimers morphology in dilute solutions by coarse grade simulation, monomer resolved simulation, and atom resolved simulations. Hydrogen bond interactions, hydrophobic interactions, and electrostatic interactions between the dendrimer-drug complexes play an important role in protein and peptide delivery as illustrated by the atomic resolved simulation approach [33]. It is a great challenge for the researchers to produce dendrimers for targeted delivery of drugs and genes for improved bioavailability.

Neurological disorders are the most life-threatening situations. Drug penetration through the BBB is difficult to treat neurological disorders [34]. Advancement in the structure of dendrimers makes it a novel carrier for the delivery of peptide drugs to the brain. Streptavidin adapter is bioconjugated with PAMAM (poly-amido-amine) dendrimer for the attachment of dendrites. Permeation of dendronized streptavidin (DSA) to the central nervous system via dendrimers has been proved in mouse, murine or porcine models. The bioconjugates were transported through the BBB via caveolae pathway via transcytosis bypassing of lysosomes. Neurons and astrocytes receive DSA after transcytosis offered high biocompatibility [35, 36].

Furthermore, third-generation PAMAM (poly-amido-amine) dendrimer has been bioconjugated with poly-ethylene-glycolated 4 carboxylic acid moieties. The four carboxylic acid moieties involved were aconitic acid, succinic acid, glutamic acid, and aspartic acid. The dendrimer was designed to cure bone disorders. The binding affinities of dendrimer conjugates were ensured via in vitro studies using calcium ions and hydroxyapatite. Dendrimers were labeled with radioactive ${ }^{111}$ In before it is checked for its deposition and bone targeting in in vivo. Dendrimer conjugated with amino acid, aspartic acid shows the best result among the rest in bone deposition and targeting in in vivo [37, 38].

PAMAM has an anti-atrophic effect. PAMAM conjugated dendrimers could increase the antigenic effect of proteins. The PAMAM dendrimer coated with recombinant baculovirus to stimulate the overexpression of vascular endothelial growth factor (a protein) could improve the repair of damage in cardiac tissues. PAMAM - angiotensin (1-7) conjugate could recover muscular fiber diameters and regulate proteins [39]. Hill et al. synthesized cyclic Arg-Gly-Asp peptide-PAMAM dendrimer-based dental implants and evaluated their binding and uptake properties in an odontoblast cell line (MDPC-23 cells). In vitro cellular uptake studies were conducted on human vascular endothelial cells, human dermal microvessel endothelial cells, or MDPC-23 cells to study the binding properties with the integrin receptors. The study recommended that PAMAM dendrimers can be used to deliver Arg-Gly-Asp peptide for odontoblast regeneration [40]. 


\subsection{Liposomes}

Liposome forms an integral part of the drug delivery system that reduces drug toxicity, dose dumping and plays an important part in the transmission of genetic materials. Liposomes have been evolved as a novel therapeutic approach for the transmission of proteins and peptides. Liposomes are used in vivo for the transmission of genetic material as an efficient vector. Components of the liposome are optimized to avoid uptake by the reticulo-endothelial system. The surface of liposomes can be modified with ligands or antibodies which help in getting it recognized by specific type of cells and hence enhance tissue targeting. Virosomes have been developed to increase the efficiency of gene delivery directly into the cell by combining fusogenic viral envelope protein with liposomes [41].

Liposome in alginate (LIA), composed of a biodegradable polymer and lipid, has been reported as a novel protein delivery approach. LIA is prepared by a double emulsification process in which a model protein called bovine serum albumin (BSA) is entrapped within the multivesicular liposomes (MSL). This is followed by the encapsulation of MSL within sodium alginate hydrogel microcapsule with entrapped BSA. BSA is added during the preparation of multivesicular liposomes. In vitro studies are carried out to assess the release of protein from the microcapsules. Simultaneously the characteristics of protein encapsulated in microcapsule formulation, multivesicular liposome, and analysis of the integrity of BSA in the microcapsules are also studied. Fabrication and composition of the LIA affected the entrapment efficiency of liposomes containing protein drug or polymer [42].

Delivery of drugs to the living cell is a major challenge nowadays and is hard to achieve. Delivery of drugs via endocytotic may result in low bioavailability due to the enzymatic degradation, consumption of drug via lysosomes, and so on. The in vitro and in vivo drug delivery to the living cell can be achieved by incorporating a complementary paired coiled-coil lipopeptide into the lipid bilayer of cell membrane and liposome. It results in the release of doxorubicin and fluorescent dyes encapsulated in liposomes with the help of a targeted membrane fusion technique. The plasma membrane is the major site for the release of drug with the help of endosome trackers and endocytosis inhibitors [43]. Transfer of TAT peptide to cellular compartment was accomplished using liposome. TAT peptide is derived from HIV1-TAT protein. The transfer of TAT protein is possible at low temperatures and in the presence of molecular inhibitors [44].

\subsection{Solid lipid nanoparticles}

Solid lipid nanoparticles [SLNs] $(30 \mathrm{~nm}-1000 \mathrm{~nm})$ are produced from degradable lipids (Figure 4). SLNs with the particle size of $120 \mathrm{~nm}$ to $200 \mathrm{~nm}$ can bypass the liver and spleen filtration. They have several advantages over other nano-formulations including increased bioavailability, easy large-scale production, low acute or chronic toxicity, both hydrophilic and lipophilic drugs can be incorporated, less solvent usage and provides protection for liable phytoconstituents [45]. Martin et al, reported drug encapsulation in SLNs by three different methods: (i) homogeneous matrix model, (ii) drug enriched shell model, and (iii) drug enriched core model. Controlled drug delivery was attained using solid lipid instead of the oil phase. The mobility of drugs in the solid lipid phase is lower than in oil phase. Proteins are protected in SLNs by their solid matrix structure which increases the release profile of proteins and protects against chemical degradation [46]. Zhang et al, compared insulin with insulin loaded solid lipid nanoparticles modified with wheat germ agglutinin-Nglutaryl-phosphatidylethanolamine (WGA-N-glut-PE). SLNs were prepared by the double emulsion dispersion method. Modified WGA insulin showed the highest drug entrapment efficiency. In vitro results showed that SLNs insulin and modified WGA SLNs insulin were protected from degradation. Modified WGA SLNs insulin was more stable than insulin SLNs [47]. Diagrammatic representation of drug-loaded solid lipid nanoparticle is shown in Figure 4 [48]. Schematic presentation of various advantages and applications of solid lipid nanoparticles is shown in Figure 5 [49].

SLNs can incorporate both hydrophilic and lipophilic compounds. Proteins are poorly incorporated into the hydrophobic phase during solidified emulsion technique (dispersed phase) hence they tend to partition into the water phase. This can be overcome by the addition of surfactants as emulsion stabilizers. SLNs containing protein have increased bioavailability, improved stability, sustained delivery of incorporated proteins, and reduced proteolytic degradation (Figure 5) [50].

\subsection{Polymeric nanoparticles}

Polymeric nanoparticles (size ranges below $100 \mathrm{~nm}$ ) provide targeted delivery of drugs. They can easily permeate through biological barriers and maintain thermodynamic balance to the system. Various advantages of polymeric nanoparticles are enhanced bioavailability of hydrophobic drugs, increased encapsulation 
efficiency, increased systemic circulation, uniform drug distribution at the target site, provide stability to acidlabile drugs, and controlled drug release. Polymeric nanoparticles are synthesized to deliver proteins and peptides due to their high encapsulation efficiency and drug protection from degradation and premature release before reaching the target site [51]. Polymeric nanoparticles have various enriched characteristics in the biological system depending on their nature, chemical modification, and functionalization with various macromolecules. Multifunctional polymeric nanoparticles are designed in association with vehicles that can regulate multiple cellular actions because of various proteins, growth factors, peptides, and cytokine therapy that play a crucial part in cellular response. This functionalization of polymeric nanoparticles takes place in two steps, first is with biological molecules e.g. proteins, peptides, lipids, carbohydrates, fatty acids, and nucleic acid, seconds is with special ligands e.g. antibodies, mono or oligosaccharides, folate receptors, biotin, and others [52].

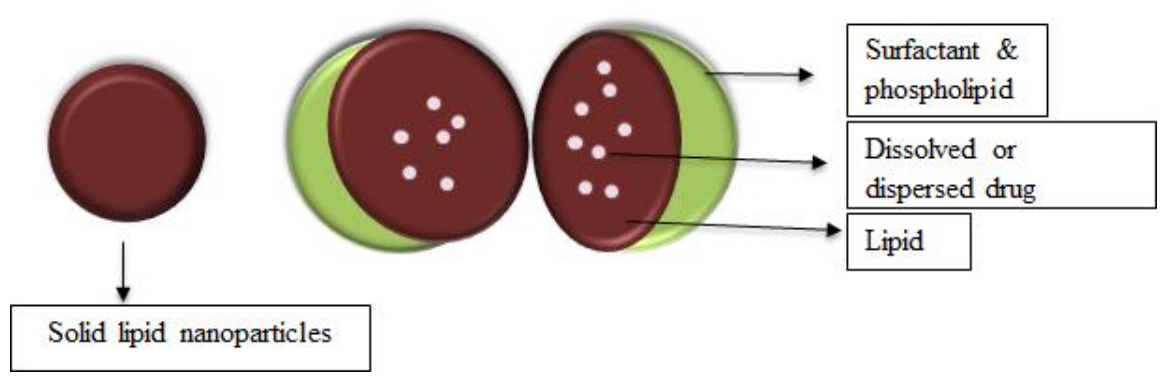

Figure 4. Diagrammatic representation of drug-loaded solid lipid nanoparticle [48].

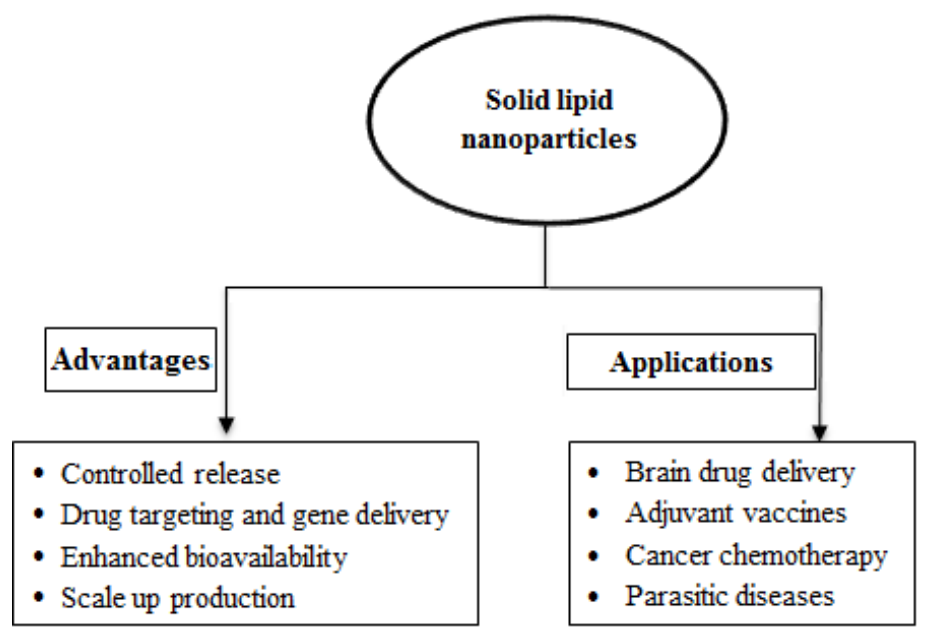

Figure 5. Schematic presentation of various advantages and applications of solid lipid nanoparticles [49].

Biodegradable polymeric nanoparticles are considered efficient for the delivery of proteins and peptides as they bound either in the inner core to form nanocapsules or they bound to the surface to form nanosphere. They are of subcellular size, they are steady during blood circulation, non-thrombogenic, do not react with tissues and cells, non-immunogenic, bypass reticuloendothelial system, non-inflammatory, non-toxic, and behave in a sustained and controlled release manner. PLGA (poly-(lactic-co-glycolic acids)) based nanoparticles have been synthesized to deliver protein vaccine [53]. Biodegradable polylactic acid (PLA) is used to deliver protein or peptide. During carbohydrate metabolism, it splits into monomeric units. Mono (6(2-aminoethyl)-amino-6-deoxy)-cyclodextrin-PLA polymer is used to encapsulate BSA. The encapsulation efficiency of protein was increased, and it was stable even after the release from nanoparticles. Hence, this copolymer can be used to encapsulate proteins [54].

Polymeric microneedles (MNs) can easily permeate through the stratum corneum. MNs can be used systematically or locally for protein and peptide delivery. Due to their unique physicochemical characteristics, MNs can effectively deliver therapeutics. These drug carriers can overcome biohazard wastes and drug stability issues. This makes it possible to procure proteins in the dry state due to the encapsulation within the polymer matrix. Thus, reduce the cost and transportation restrictions. Approaches for the manufacturing of polymeric MNs are: (i) for direct delivery, solid MNs are coated with polymeric drug preparation on MNs 
surface where drug release depends on dissolution of coating shell, (ii) in dissolvable polymeric MNs the polymeric drug preparation is incorporated in the matrix and drug efficiency is estimated by the dissolution of encapsulated drug within the skin, iii) polymeric drug preparation was encapsulated via passive diffusion and polymer matrix degrades over a period for release, iv) formulation from MNs matrix dissociates or degrades and release occurs in a bioresponsive manner [55]. Table 2 presents various polymers investigated for the delivery of proteins and peptides.

Table 2. List of polymers investigated to synthesize nanoformulations for topical drug delivery.

\begin{tabular}{lll}
\hline Polymers & Effect & Ref. \\
\hline Natural polymers- hydrogels & Collagen gels are thermally reversible, slower gel degradation & \\
Collagen & rate prolonged vascular endothelial growth factor retention & {$[56]$} \\
Gelatin & Sustained release of protein, reduced cytotoxicity & {$[56]$} \\
Fibrin & No toxic degradation, no inflammatory reactions & {$[56]$} \\
Alginate & Proliferation rate increases & {$[56]$} \\
Chitosan & Increase quasi-linear release & \\
Hydrogels- synthetic polymers & \\
Poly(ethylene & Stabilization, controlled release, and temperature dependent sol- \\
oxide) & to-gel formation & {$[57]$} \\
Poly(acrylic acid) & Controlled release, enhance oral delivery of protein and peptide & {$[56]$} \\
Polyvinyl alcohol & Stable, controlled release, elastic delivery, and delivery of water- & {$[58]$} \\
& soluble drugs & \\
\hline
\end{tabular}

\subsection{Polymeric micelles}

Micelles containing amphiphilic molecules can easily reach the target site. Thus, these carriers can be used for the effective delivery of protein and peptides. Poorly water-soluble drugs are easily solubilized in the internal core of micelles due to their hydrophobic environment [59]. Micelles are used as an effective drug delivery system because they provides advantages such as minimum loss of drug or drug disposition, drug degradation, increases drug bioavailability to the target site, prevent side effects, and enhance drug stability.

The production approaches for polymeric micelles include (a) use of organic solvents and (b) direct dissolution. In the former method, both the drug and copolymer are not freely soluble in water. Here, initially, both the components are dissolved in a common solvent. The solvent can be removed either by the dialysis method (if the solvent is water-miscible) or by the oil-in-water emulsion method (if the solvent is not miscible with water). In the direct method, both the drug and polymer are dissolved in an aqueous media. Poloxamer such as poly(ethylene oxide)-b-poly(propylene oxide)-b-poly(ethylene oxide) is the most commonly used polymers in the synthesis of polymeric micelles by direct dissolution method [60].

Various micellar systems such as lipoproteins, natural and synthetic insoluble polymer, soluble polymer, cell ghosts, and amphiphilic molecules are used as vehicles for the delivery of protein drugs. These micelles have some shortcomings along with advantages. Surfactants (low molecular weight) are used in drug delivery devices faces shortcoming like kinetic and thermodynamic instability due to their large CMC values. Polymeric micelles provide high stability, increased cargo capacity, controlled drug release, and non-toxicity when compared to liposomes.

Polymeric micelles show prolonged circulation time when administered intravenously, due to its hydrophilic shell and smaller size. It helps polymeric micelles to escape the mono phagocytic system for its phagocytosis. Due to their high molecular weight, polymeric micelles can be prevented from renal excretion. Polymeric micelles loaded with a drug has come out to be an efficient tool in pharmaceutical approach to the target tumour. Polymeric micelle loaded with drug reduces its distribution to the non-target site such as heart. Polymeric micelles provide certain advantages such as impaired lymphatic drainage and increased vascular permeation. This leads to more accumulation in the inflamed or malignant tumour tissues [61].

Polymeric micelles have been developed to treat neurodegenerative disorders such as Parkinson's and Alzheimer's diseases, HIV-associated dementia, and brain stroke. Polymeric micelles provide an advantage of delivering the biologically active ingredient to the brain by passing the blood-brain barrier [62]. Two strategies have been developed to bypass the BBB via polymeric micelles. In the first strategy, the surface of polymeric micelles is loaded with ligand molecules or antibodies capable of producing transcytosis across the BBB 
comprising of micro-vessels endothelial cells. In the second strategy, a polymeric micelle is loaded with pluronic block copolymer and hence results in minimal drug efflux and increases the permeability of the BBB [63].

Block copolymer micelle came into existence, providing an excellent way as long-circulating drug vehicle. Poly (L-amino acid) and poly(ethylene oxide) are used as a hydrophobic block and hydrophilic block, respectively [64]. Immunomicelles have been developed to increase the bioavailability of the poor soluble protein drug. Immunomicelles comprised of polyethylene glycol-phosphatidylethanolamine conjugates are combined with micelle attached antibodies in the corona of the micelles.

\section{PATENTED NANOCARRIERS FOR DELIVERY OF PROTEINS AND PEPTIDES}

Technical and scientific indicators need to get significant attention to explore the existing state of the art of a specific field. Patenting a new product or process is important to protect the intellectual property of the innovator from being explored by a third party in an unauthorized manner [65]. Many nano carrier-based drug delivery systems have been patented for the delivery of proteins and peptides for their improved biomedical applications by overcoming the limitations of biological barriers (Table 3).

As evident from the literature, the peptide and proteins market has been segmented depending on health issues like metabolic disorders, cardiovascular disorders, cancer therapeutics, etc. Apart from these disorders, these biomacromolecules have been used for the treatment of respiratory disorders, infections, and hematological disorders. Several companies are involved in developing protein and peptide-based drugs (Table 4 and 5).

Table 3. Patents on nanocarriers based protein and peptide delivery systems.

\begin{tabular}{|c|c|c|c|c|}
\hline Patent number & Patent title & Description & $\begin{array}{l}\text { Publication/ } \\
\text { grant date }\end{array}$ & Ref. \\
\hline US20160220502 & $\begin{array}{l}\text { Potato protein } \\
\text { nanoparticles }\end{array}$ & $\begin{array}{l}\text { This invention provides a } \\
\text { nanoparticle made of a potato } \\
\text { protein; and a bioactive compound } \\
\text { bound to the potato protein }\end{array}$ & 04.08.2016 & {$[66]$} \\
\hline WO2007086613 & $\begin{array}{l}\text { Enzymatically crosslinked } \\
\text { protein nanoparticles }\end{array}$ & $\begin{array}{l}\text { It provides a protein nanoparticle } \\
\text { that is obtained by enzymatic } \\
\text { crosslinking during and/or after } \\
\text { the formation of protein } \\
\text { nanoparticle }\end{array}$ & 02.08.2007 & [67] \\
\hline US $15 / 547,404$ & $\begin{array}{l}\text { Nanoparticle-protein } \\
\text { complex for intracellular } \\
\text { protein delivery }\end{array}$ & $\begin{array}{l}\text { The present invention provides a } \\
\text { nanoparticle-protein complex } \\
\text { including a nanoparticle carrying } \\
\text { an amine-containing ligand }\end{array}$ & 04.08.2016 & {$[68]$} \\
\hline CN109956995 & $\begin{array}{l}\text { Paclitaxel-loaded semen } \\
\text { armeniacae amarae } \\
\text { protein nanocarrier and } \\
\text { preparation method } \\
\text { thereof }\end{array}$ & $\begin{array}{l}\text { The nanocarrier is formed by heat } \\
\text { induction of semen armeniacae } \\
\text { amarae protein monomers }\end{array}$ & 02.07.2019 & [69] \\
\hline KR1018250290000 & $\begin{array}{l}\text { Hydrogel nano carrier } \\
\text { derived from goat milk } \\
\text { protein resolvent and } \\
\text { manufacturing method } \\
\text { thereof }\end{array}$ & $\begin{array}{l}\text { The nanocarrier including a goat } \\
\text { milk protein resolvent which can } \\
\text { be widely used by infants or } \\
\text { elderly people who have milk } \\
\text { protein intolerance or have } \\
\text { degraded digestive functions }\end{array}$ & 14.03.2018 & [69] \\
\hline CN106692978 & $\begin{array}{l}\text { Zein/protein- } \\
\text { polysaccharide } \\
\text { electrostatic complex } \\
\text { core/shell type } \\
\text { nanocarrier as well as } \\
\text { preparation method and } \\
\text { application thereof }\end{array}$ & $\begin{array}{l}\text { The invention discloses a zein/ } \\
\text { protein-polysaccharide } \\
\text { electrostatic complex core/shell } \\
\text { type nanocarrier which is a nano } \\
\text { microsphere, wherein zein serves } \\
\text { as a core, and the exterior is coated } \\
\text { with a protein-polysaccharide } \\
\text { electrostatic complex to be served } \\
\text { as a shell }\end{array}$ & 14.02 .2020 & [70] \\
\hline WO2011050178A3 & $\begin{array}{l}\text { Targeted PRDM gene or } \\
\text { protein modulation } \\
\text { therapeutic agents }\end{array}$ & $\begin{array}{l}\text { A medicinal new chemical entity is } \\
\text { created when a targeted } \\
\text { nanocarrier is combined with a } \\
\text { PRDM gene- or protein- } \\
\text { modulating agent }\end{array}$ & 22.09 .2011 & [71] \\
\hline
\end{tabular}


Table 4. List of marketed nano-formulations for protein and peptide delivery [48, 72-74].

\begin{tabular}{|c|c|c|c|c|}
\hline Trade name & Generic name & Composition & Description/ Indications & Company \\
\hline Abraxane $^{\circledR}$ & $\begin{array}{l}\text { Albumin bound } \\
\text { paclitaxel }\end{array}$ & $\begin{array}{l}\text { Protein } \\
\text { nanoparticle }\end{array}$ & Breast cancer, lung cancer & Abraxis \\
\hline Ontak ${ }^{\circledR}$ & $\begin{array}{l}\text { Denileukin } \\
\text { diftitox }\end{array}$ & $\begin{array}{l}\text { Protein } \\
\text { combining } \\
\text { interleukin-2 } \\
\text { and diphtheria } \\
\text { toxin }\end{array}$ & $\begin{array}{l}\text { Cutaneous T-cell } \\
\text { lymphoma }\end{array}$ & $\begin{array}{l}\text { Ligand } \\
\text { Pharm, Inc. }\end{array}$ \\
\hline $\begin{array}{l}\text { Sandostatin } \\
\text { Lar }^{\circledR}\end{array}$ & $\begin{array}{l}\text { Octreotide } \\
\text { Acetate }\end{array}$ & PLGA & Acromegaly & Novartis \\
\hline Adagen $^{\circledR}$ & $\begin{array}{l}\text { PEG-adinosin } \\
\text { deamidase }\end{array}$ & $\begin{array}{l}\text { PEGylated } \\
\text { proteins }\end{array}$ & $\begin{array}{l}\text { Extend residence time of } \\
\text { proteins in blood, decrease } \\
\text { immunogenicity, decreases } \\
\text { plasma clearance rate, } \\
\text { slow down metabolic } \\
\text { degradation, improve oral } \\
\text { absorption of proteins and } \\
\text { increases safety profile of } \\
\text { proteins. }\end{array}$ & Enzon \\
\hline PegIntron ${ }^{\circledR}$ & $\begin{array}{l}\text { PEG- } a- \\
\text { interferon-2b }\end{array}$ & $\begin{array}{l}\text { PEGylated } \\
\text { proteins }\end{array}$ & $\begin{array}{l}\text { Treat hepatitis } \mathrm{C} \text { and } \\
\text { melanoma }\end{array}$ & $\begin{array}{l}\text { Schering } \\
\text { Plough }\end{array}$ \\
\hline Oncaspar ${ }^{\circledR}$ & $\begin{array}{l}\text { PEG-L- } \\
\text { Asparaginase }\end{array}$ & $\begin{array}{l}\text { PEGylated } \\
\text { proteins }\end{array}$ & $\begin{array}{l}\text { Treatment of acute } \\
\text { lymphoblastic leukemia }\end{array}$ & Enzon \\
\hline Pegasys ${ }^{\circledR}$ & $\begin{array}{l}\text { PEG- } a- \\
\text { interferon-2a }\end{array}$ & $\begin{array}{l}\text { PEGylated } \\
\text { proteins }\end{array}$ & $\begin{array}{l}\text { Treat hepatitis C and } \\
\text { hepatitis B }\end{array}$ & Roche \\
\hline Somavert ${ }^{\circledR}$ & Pegvisomant & $\begin{array}{l}\text { PEGylated } \\
\text { proteins }\end{array}$ & $\begin{array}{l}\text { Growth hormone receptor } \\
\text { antagonist used in the } \\
\text { treatment of acromegaly }\end{array}$ & Pfizer \\
\hline
\end{tabular}

\section{CURRENT AND FUTURE DEVELOPMENTS}

Increased market demand for nanotechnology-based formulations for many therapeutic agents has attracted the attention of pharmaceutical scientists to overcome the limitations of conventional proteins and peptide delivery. Table 6 presents major peptide-based products under preclinical and clinical investigations. Nanoparticles provide an opportunity for improved therapeutic outcomes of these biomacromolecules due to their small particle size, high encapsulation, and targeting capacity. Table 7 presents various proteins, targeting ligands and their functional activity. Low dose and targeted delivery of bioactives lead to reduce toxicity [100]. During the past few years, a gradual increase in the number of marketed formulations, patents, and clinical trials on nanoformulations for delivery of proteins and peptides has been noted [101, 102].

\section{CONCLUSION}

Oral delivery of peptides and proteins has endless challenges. The oral bioavailability of biomacromolecules like proteins and peptides is less than $1 \%$. Nanocarriers are emerging as a smart promising drug delivery carrier to overcome the limitations of biological barriers and able to optimize cellular uptake and control the intracellular fate. Based on the literature evidence, nanocarriers are predicted to have a foremost role in the delivery of these biomacromolecules. The market potential of nanocarrier based protein and peptide therapeutics is rapidly expanding. 
Table 5. Companies expending on the development of protein and peptide delivery systems [48, 75, 76].

\begin{tabular}{|c|c|c|c|c|}
\hline Company & Carrier system & Product & Remark & $\begin{array}{l}\text { Availability in } \\
\text { market }\end{array}$ \\
\hline $\begin{array}{l}\text { Apollo Life } \\
\text { Sciences }\end{array}$ & Nanoparticles & Oradel $^{\mathrm{TM}}$ & $\begin{array}{l}\text { To carry protein-based drugs } \\
\text { and antibodies across the } \\
\text { intestinal cell wall for } \\
\text { transportation of large and } \\
\text { small molecules of protein and } \\
\text { peptide or antibodies and to } \\
\text { protect the drug from digestive } \\
\text { enzymes }\end{array}$ & $\begin{array}{l}\text { Oral delivery of } \\
\text { anti-inflammatory } \\
\text { proteins and } \\
\text { insulin }\end{array}$ \\
\hline Endorex & $\begin{array}{l}\text { Polymerized } \\
\text { liposome }\end{array}$ & Orasome $\mathrm{TM}^{\mathrm{TM}}$ & $\begin{array}{l}\text { To preserve proteins from } \\
\text { degradation in the stomach and } \\
\text { upper gastrointestinal tract }\end{array}$ & $\begin{array}{l}\text { Vaccines, insulin, } \\
\text { and human growth } \\
\text { hormones }\end{array}$ \\
\hline Emisphere & Carrier molecules & Eligen $^{\circledR}$ & $\begin{array}{l}\text { All the sizes of drug molecules } \\
\text { can cross cell membrane with } \\
\text { the help of passive transcellular } \\
\text { transport and without changes } \\
\text { in the pharmacological } \\
\text { properties, chemical form, and } \\
\text { biological integrity the } \\
\text { absorption of small molecules } \\
\text { increases }\end{array}$ & $\begin{array}{l}\text { Heparin, growth } \\
\text { hormone, } \\
\text { parathyroid } \\
\text { hormone, } \\
\text { calcitonin, PYY, } \\
\text { GPL-1, and insulin }\end{array}$ \\
\hline PLC Provalis & $\begin{array}{l}\text { Micro-emulsion } \\
\text { lipid-based water- } \\
\text { in-oil }\end{array}$ & Macrulin $^{\mathrm{TM}}$ & $\begin{array}{l}\text { In the treatment of Type- } 2 \\
\text { diabetes, boost up the protein } \\
\text { absorption in GIT and } \\
\text { safeguard proteins against } \\
\text { acidic degradation and } \\
\text { proteolysis }\end{array}$ & $\begin{array}{l}\text { Salmon calcitonin } \\
\text { and insulin }\end{array}$ \\
\hline Biocon or NOBEX & $\begin{array}{l}\text { Amphiphilic } \\
\text { oligomers }\end{array}$ & HIM2 & $\begin{array}{l}\text { Enhance permeation through } \\
\text { membrane and prevent } \\
\text { digestion against enzyme }\end{array}$ & $\begin{array}{l}\text { Enkephalin, } \\
\text { parathyroid } \\
\text { hormone, insulin, } \\
\text { and calcitonin }\end{array}$ \\
\hline Generex & $\begin{array}{l}\text { Aerosol particles / } \\
\text { Spray device }\end{array}$ & Oral-Lyn ${ }^{\mathrm{TM}}$ & $\begin{array}{l}\text { Therapy for Type- } 1 \& 2 \\
\text { diabetes and easy pass-through } \\
\text { buccal epithelium }\end{array}$ & $\begin{array}{l}\text { Macrotonin and } \\
\text { insulin }\end{array}$ \\
\hline Altus & $\begin{array}{l}\text { Protein } \\
\text { crystallization }\end{array}$ & CLEC $^{\circledR}$ & $\begin{array}{l}\text { Safeguard protein against self- } \\
\text { digestion and proteolysis and } \\
\text { act as a catalyst consist of } \\
\text { enzyme ADH (alcohol } \\
\text { dehydrogenase) }\end{array}$ & $\begin{array}{l}\text { Proteases, lipases, } \\
\text { esterases, calcitonin } \\
\text { and other } \\
\text { polypeptides }\end{array}$ \\
\hline Novartis & & Sandostatin LAR ${ }^{\circledR}$ & & Octreotide acetate \\
\hline Debiopharm & Nanoparticles / & $\begin{array}{l}\text { Decapeptyl } \\
\text { Depot }^{\circledR}\end{array}$ & $\begin{array}{l}\text { Increasing in vivo half-lives of } \\
\text { proteins and peptides, } \\
\text { increasing parenteral delivery, }\end{array}$ & $\begin{array}{l}\text { LHRH (Luteinizing } \\
\text { hormone releasing } \\
\text { hormone) }\end{array}$ \\
\hline Genetech & & Nutropin Depot ${ }^{\circledR}$ & $\begin{array}{l}\text { and protecting from } \\
\text { degradation }\end{array}$ & $\begin{array}{l}\text { Human growth } \\
\text { hormone }\end{array}$ \\
\hline Takeda Abbot & & Lupron Depot ${ }^{\circledR}$ & & LHRH \\
\hline $\begin{array}{l}\text { Phoreus } \\
\text { Biotechnology }\end{array}$ & Lipid nanocarriers & $\begin{array}{l}\text { Branched } \\
\text { Amphipathic } \\
\text { Peptide } \\
\text { Capsules }^{\mathrm{TM}} \\
\text { (BAPC) }\end{array}$ & $\begin{array}{l}\text { Solves the problem of poor } \\
\text { absorption for various drugs, } \\
\text { both lipophilic and hydrophilic } \\
\text { drugs, small molecule, } \\
\text { proteins, and nucleic acids, can } \\
\text { be able to bind with BAPC, } \\
\text { increase the delivery efficacy of } \\
\text { cancer therapies, alternative } \\
\text { antibiotics, novel vaccines and } \\
\text { biopesticides }\end{array}$ & - \\
\hline Eligo Bioscience & $\begin{array}{l}\text { Nano delivery } \\
\text { carriers }\end{array}$ & ELigobiotics $^{\circledR}$ & $\begin{array}{l}\text { Used for microbial population } \\
\text { to functionalize, diagnose, or } \\
\text { eradicate }\end{array}$ & 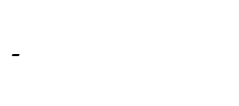 \\
\hline Fresenius Kabi & Polymeric delivery & HESylation $^{\circledR}$ & $\begin{array}{l}\text { Improves pharmacokinetics } \\
\text { and pharmacodynamics of the } \\
\text { drug }\end{array}$ & $\begin{array}{l}\text { Erythropoietin, } \\
\text { Granulocyte colony } \\
\text { stimulating factor }\end{array}$ \\
\hline $\begin{array}{l}\text { Nektar } \\
\text { Therapeutics }\end{array}$ & Colloidal carriers & TheraPG ${ }^{\mathrm{TM}}$ & $\begin{array}{l}\text { Pegylation of small and large } \\
\text { molecules of proteins }\end{array}$ & PG \\
\hline
\end{tabular}


Table 6. List of major peptide-based products under preclinical and clinical investigations [77-79].

\begin{tabular}{|c|c|c|c|c|}
\hline Company & $\begin{array}{l}\text { Peptide } \\
\text { Name }\end{array}$ & Target & $\begin{array}{l}\text { Dosing } \\
\text { Regimen }\end{array}$ & $\begin{array}{l}\text { Development } \\
\text { Stage }\end{array}$ \\
\hline Lilly & Cpd86 & GLP-1/GIP & SC, once daily & Preclinical \\
\hline Zealand Pharm & ZPGG-72, ZP3022 & $\begin{array}{l}\text { GLP-1/GLP-2, } \\
\text { GLP-1/CCKB }\end{array}$ & SC, once daily & Preclinical \\
\hline Novo Nordisk & NN9926 & GLP-1 & $\begin{array}{l}\text { Oral, long } \\
\text { acting }\end{array}$ & Phase I \\
\hline Zydus-Cadila & ZYOG1 & GLP-1 & Oral & Phase I \\
\hline Roche & MAR709 & GLP-1/GIP & SC, once daily & Phase II \\
\hline Eli Lilly & TT401 & GLP-1/GCG & SC, once daily & Phase II \\
\hline Novo Nordisk & Semaglutide & GLP-1 & SC, once daily & Phase III \\
\hline Intarcia & ITCA & GLP-1 & SC, once daily & Phase III \\
\hline Novo Nordisk & GIPET & NN1956 & Oral & Phase I \\
\hline Novo Nordisk & Insulin Gargine & - & SC & Phase II \\
\hline $\begin{array}{l}\text { Merrion } \\
\text { Pharma }\end{array}$ & GIPET & - & Oral & Complete \\
\hline $\begin{array}{l}\text { Diasome } \\
\text { Pharm }\end{array}$ & HDV-I & - & Oral & Phase II \\
\hline- & Neoral & - & Oral & Pre-clinical \\
\hline AlphaRx Inc. & $\begin{array}{l}\text { TrabiOral, } \\
\text { Rifamsolin, } \\
\text { Ocusolin, } \\
\text { Vansolin, Zysolin }\end{array}$ & - & Oral & Pre-clinical \\
\hline $\begin{array}{l}\text { Aileron } \\
\text { Therapeutics, } \\
\text { Inc. }\end{array}$ & ALRN-6924 & $\begin{array}{l}\text { MDM2/MDM } \\
\mathrm{X}\end{array}$ & - & Phase II \\
\hline \multicolumn{5}{|c|}{$\begin{array}{l}\text { GLP-1: Glucagon-like peptide-1 agonists, CCKB: cholecystokinin B receptor, } \\
\text { inhibitory polypeptide, MDM2: mouse double minute } 2 \\
\text { Table 7. Proteins as targeting ligands and functional activity. }\end{array}$} \\
\hline $\begin{array}{l}\text { Protein/ } \\
\text { ligand }\end{array}$ & \multicolumn{3}{|l|}{ Characteristics } & Ref. \\
\hline Albumin & \multirow{2}{*}{\multicolumn{3}{|c|}{$\begin{array}{l}\text { Albumin is a major serum protein; it has binding } \\
\text { sites for lipophilic drugs including steroids. } \\
\text { Elastin is a crosslinked protein present in the } \\
\text { extracellular matrix. It is responsible for the elasticity of } \\
\text { tissues. }\end{array}$}} & 80 \\
\hline Elastin & & & & 81 \\
\hline Insulin & \multicolumn{3}{|c|}{$\begin{array}{l}\text { Insulin is a hormone which mainly regulates blood } \\
\text { glucose levels. }\end{array}$} & 82 \\
\hline $\begin{array}{l}\text { Lectin (wheat } \\
\text { germ } \\
\text { agglutinin) }\end{array}$ & \multicolumn{3}{|c|}{$\begin{array}{l}\text { Lectin binds to human enterocytes and CACO-2 cell } \\
\text { surface. }\end{array}$} & $83-89$ \\
\hline RGD peptide & \multirow{2}{*}{\multicolumn{3}{|c|}{$\begin{array}{l}\text { It increases the spreading of cells and enhances DNA } \\
\text { synthesis. It minimizes the risk of immune reactivity. } \\
\text { Iron-loaded transferring promotes the uptake of iron by } \\
\text { the interaction with the Transferrin receptor which is } \\
\text { used as a targeting ligand for anticancer agents, genes, } \\
\text { and proteins. }\end{array}$}} & $90-94$ \\
\hline Transferrin & & & & $95-99$ \\
\hline
\end{tabular}

Author contributions: Concept - R.A.; Design - S.S., V.S., B.B.; Supervision - R.A, G.T.K.; Resource - S.S., V.S., B.B., R.A., R.M., G.T.K.; Materials - S.S., V.S., B.B., R.A., R.M., G.T.K.; Data Collection \&/or Processing - S.S., V.S., B.B., R.M.; Analysis \&/or Interpretation - R.M., R.M., G.T.K.; Literature Search - S.S., V.S., R.A., B.B.; Writing - S.S., V.S., R.A.; Critical Reviews - S.S., V.S., B.B., R.M., R.A., G.T.K.

Conflict of interest statement: The authors declare no conflict of interest. 


\section{REFERENCES}

[1] Joseph M, Trinh HM, Mitra AK. Peptide and Protein-Based Therapeutic Agents. In Emerging Nanotechnologies for Diagnostics, Drug Delivery and Medical Devices. 2017; 146. [CrossRef]

[2] Cao SJ, Xu S, Wang HM, Ling Y, Dong J, Xia RD, Sun XH. Nanoparticles: oral delivery for protein and peptide drugs. AAPS PharmSciTech. 2019; 20(5): 190. [CrossRef]

[3] Global Peptide Therapeutics Market \& Clinical Pipeline Insight 2026. Research and Markets. Available from: https:/ / www.researchandmarkets.com/reports/4896465/global-peptide-therapeutics-market-andclinical?utm_code $=5 \mathrm{c} 6 \mathrm{~d} 7 \mathrm{v} \& u t m \_$medium $=\mathrm{GN}$. (Accessed on July 14, 2020).

[4] Patel A, Patel M, Yang X, K Mitra A. Recent advances in protein and peptide drug delivery: a special emphasis on polymeric nanoparticles. Protein Pept Lett. 2014; 21(11): 1102-1120. [CrossRef]

[5] Majumder J, Taratula O, Minko T. Nanocarrier-based systems for targeted and site specific therapeutic delivery. Adv Drug Deliv Rev. 2019; 144: 57-77. [CrossRef]

[6] Lee AC, Harris JL, Khanna KK, Hong JH. A comprehensive review on current advances in peptide drug development and design. Int J Mol Sci. 2019; 20(10): 1-21. [CrossRef]

[7] Tesauro D, Accardo A, Diaferia C, Milano V, Guillon J, Ronga L, Rossi F. Peptide-based drug-delivery systems in biotechnological applications: Recent advances and perspectives. Molecules. 2019; 24(2): 1-27. [CrossRef]

[8] Su C, Liu Y, Li R, Wu W, Fawcett JP, Gu J. Absorption, distribution, metabolism and excretion of the biomaterials used in Nanocarrier drug delivery systems. Adv Drug Deliv Rev. 2019; 143: 97-114. [CrossRef]

[9] Bayón-Cordero L, Alkorta I, Arana L. Application of Solid Lipid Nanoparticles to Improve the Efficiency of Anticancer Drugs. Nanomaterials. 2019; 9(3): 1-20. [CrossRef]

[10] Singh AP, Biswas A, Shukla A, Maiti P. Targeted therapy in chronic diseases using nanomaterial-based drug delivery vehicles. Signal Transduct Target Ther. 2019; 4(33): 1-21. [CrossRef]

[11] Kompella UB, Lee VH. Delivery systems for penetration enhancement of peptide and protein drugs: design considerations. Adv Drug Deliv Rev. 2001; 46(1-3): 211-245. [CrossRef]

[12] Aguirre TA, Teijeiro-Osorio D, Rosa M, Coulter IS, Alonso MJ, Brayden DJ. Current status of selected oral peptide technologies in advanced preclinical development and in clinical trials. Adv Drug Deliv Rev. 2016; 106: $223-241$. [CrossRef]

[13] Bruno BJ, Miller GD, Lim CS. Basics and recent advances in peptide and protein drug delivery. Ther Deliv. 2013;4(11):1443-67. [CrossRef]

[14] Awasthi R, Rathbone MJ, Hansbro PM, Bebawy M, Dua K. Therapeutic prospects of microRNAs in cancer treatment through nanotechnology. Drug Deliv Transl Res. 2018;8(1):97-110. [CrossRef]

[15] Cuggino JC, Blanco ER, Gugliotta LM, Igarzabal CI, Calderón M. Crossing biological barriers with nanogels to improve drug delivery performance. J Controll Rel. 2019;307:221-246. [CrossRef]

[16] Shaji J, Patole V. Protein and peptide drug delivery: oral approaches. Ind J Pharm Sci. 2008; 70(3): 269-277. [CrossRef]

[17] Homayun B, Lin X, Choi HJ. Challenges and recent progress in oral drug delivery systems for biopharmaceuticals. Pharmaceutics. 2019; 11(3): 129. [CrossRef]

[18] Langguth P, Bohner V, Heizmann J, Merkle HP, Wolffram S, Amidon GL, Yamashita S. The challenge of proteolytic enzymes in intestinal peptide delivery. J Control Release. 1997; 46(1-2): 39-57. [CrossRef]

[19] Tulain UR, Ahmad M, Rashid A, Malik MZ, Iqbal FM. Fabrication of pH-responsive hydrogel and its in vitro and in vivo evaluation. Adv Polym Tech. 2018;37(1):290-304. [CrossRef]

[20] Agarwal V, Khan MA. Current status of the oral delivery of insulin. Pharm Technol. 2001; 10: 76-90.

[21] Whitcomb DC, Lowe ME. Human pancreatic digestive enzymes. Dig Dis Sci. 2007; 52(1): 1-7. [CrossRef]

[22] Bastian SE, Walton PE, Ballard FJ, Belford DA. Transport of IGF-I across epithelial cell monolayers. J Endocrinol. 1999; 162(3): 361-370. [CrossRef]

[23] De France KJ, Hoare T, Cranston ED. Review of hydrogels and aerogels containing nanocellulose. Chem Mater. 2017;29(11):4609-4631. [CrossRef]

[24] De France KJ, Chan KJ, Cranston ED, Hoare T. Enhanced mechanical properties in cellulose nanocrystal-poly (oligoethylene glycol methacrylate) injectable nanocomposite hydrogels through control of physical and chemical cross-linking. Biomacromolecules. 2016;17(2):649-660. [CrossRef] 
[25] Kenngott EE, Cole S, Hein WR, Hoffmann U, Lauer U, Maass D, Moore L, Pfeil J, Rosanowski S, Shoemaker CB, Umair S. Identification of targeting peptides for mucosal delivery in sheep and mice. Mol Pharm. 2016; 13(1): 202210. [CrossRef]

[26] Kang SK, Woo JH, Kim MK, Woo SS, Choi JH, Lee HG, Lee NK, Choi YJ. Identification of a peptide sequence that improves transport of macromolecules across the intestinal mucosal barrier targeting goblet cells. J Biotechnol. 2008; 135(2): 210-6. [CrossRef]

[27] Li, X.; Chen, D.; Le, C.; Zhu, C.; Gan, Y.; Hovgaard, L.; Yang, M. Novel mucus-penetrating liposomes as a potential oral drug delivery system: Preparation, in vitro characterization, and enhanced cellular uptake. Int J Nanomed. 2011; 6: 3151-3162. [CrossRef]

[28] $\mathrm{Cu} \mathrm{Y,} \mathrm{Saltzman} \mathrm{WM.} \mathrm{Controlled} \mathrm{surface} \mathrm{modification} \mathrm{with} \mathrm{poly} \mathrm{(ethylene)} \mathrm{glycol} \mathrm{enhances} \mathrm{diffusion} \mathrm{of} \mathrm{PLGA}$ nanoparticles in human cervical mucus. Mol Pharm. 2009; 6(1): 173-181. [CrossRef]

[29] Müller C, Leithner K, Hauptstein S, Hintzen F, Salvenmoser W, Bernkop-Schnürch A. Preparation and characterization of mucus-penetrating papain/poly (acrylic acid) nanoparticles for oral drug delivery applications. J Nanopart Res. 2013; 15(1): 1353. [CrossRef]

[30] Kamei N, Morishita M, Takayama K. Importance of intermolecular interaction on the improvement of intestinal therapeutic peptide/protein absorption using cell-penetrating peptides. J Control Release. 2009; 136(3): 179-86. [CrossRef]

[31] Reinholz J, Landfester K, Mailänder V. The challenges of oral drug delivery via nanocarriers. Drug Deliv. 2018; 25(1): 1694-1705. [CrossRef]

[32] Yang Y, Chen Q, Lin J, Cai Z, Liao G, Wang K, Bai L, Zhao P, Yu Z. Recent advance in polymer based microspheric systems for controlled protein and peptide delivery. Curr Med Chem. 2019; 26(13): 2285-2296. [CrossRef]

[33] Ma YQ. Theoretical and computational studies of dendrimers as delivery vectors. Chem Soc Rev. 2013; 42(2): 705727. [CrossRef]

[34] Guixer B, Arroyo X, Belda I, Sabidó E, Teixidó M, Giralt E. Chemically synthesized peptide libraries as a new source of BBB shuttles. Use of mass spectrometry for peptide identification. J Pept Sci. 2016; 22(9): 577-591. [CrossRef]

[35] Li Y, Zheng X, Gong M, Zhang J. Delivery of a peptide-drug conjugate targeting the blood brain barrier improved the efficacy of paclitaxel against glioma. Oncotarget. 2016; 7(48): 79401-79407. [CrossRef]

[36] Moscariello P, Ng DY, Jansen M, Weil T, Luhmann HJ, Hedrich J. Brain delivery of multifunctional dendrimer protein bioconjugates. Adv Sci. 2018; 5(5): 1700897. [CrossRef]

[37] Yamashita S, Katsumi H, Hibino N, Isobe Y, Yagi Y, Kusamori K, Sakane T, Yamamoto A. Development of PEGylated carboxylic acid-modified polyamidoamine dendrimers as bone-targeting carriers for the treatment of bone diseases. J Control Release. 2017; 262: 10-17. [CrossRef]

[38] Tunki L, Kulhari H, Sistla R, Pooja D. Dendrimer-based targeted drug delivery. Pharmaceutical Applications of Dendrimers. 2020: 107-129. [CrossRef]

[39] Araújo RV, Santos SD, Igne Ferreira E, Giarolla J. New advances in general biomedical applications of PAMAM dendrimers. Molecules. 2018; 23(11): 2849. [CrossRef]

[40] Hill E, Shukla R, Park SS, Baker Jr JR. Synthetic PAMAM-RGD conjugates target and bind to odontoblast-like MDPC 23 cells and the predentin in tooth organ cultures. Bioconjugate Chem. 2007;18(6):1756-62. [CrossRef]

[41] Kaneda Y. Virosomes: evolution of the liposome as a targeted drug delivery system. Adv Drug Deliv Reviews. 2000; 43(2-3): 197-205. [CrossRef]

[42] Dai C, Wang B, Zhao H, Li B, Wang J. Preparation and characterization of liposomes-in-alginate (LIA) for protein delivery system. Colloids Surf B: Biointerfaces. 2006; 47(2): 205-210. [CrossRef]

[43] Yang J, Bahreman A, Daudey G, Bussmann J, Olsthoorn RC, Kros A. Drug delivery via cell membrane fusion using lipopeptide modified liposomes. ACS Cent Sci. 2016; 2(9): 621-30. [CrossRef]

[44] Torchilin VP, Rammohan R, Weissig V, Levchenko TS. TAT peptide on the surface of liposomes affords their efficient intracellular delivery even at low temperature and in the presence of metabolic inhibitors. PNAS. 2001; 98(15): 87868791. [CrossRef]

[45] Ganesan P, Ramalingam P, Karthivashan G, Ko YT, Choi DK. Recent developments in solid lipid nanoparticle and surface-modified solid lipid nanoparticle delivery systems for oral delivery of phyto-bioactive compounds in various chronic diseases. Int J Nanomed. 2018; 13: 1569-1583. [CrossRef] 
[46] Martins S, Sarmento B, Ferreira DC, Souto EB. Lipid-based colloidal carriers for peptide and protein deliveryliposomes versus lipid nanoparticles. Int J Nanomed. 2007; 2(4): 595-607.

[47] Zhang N, Ping Q, Huang G, Xu W, Cheng Y, Han X. Lectin-modified solid lipid nanoparticles as carriers for oral administration of insulin. Int J Pharm. 2006; 327(1-2): 153-159. [CrossRef]

[48] Mishra V, Bansal KK, Verma A, Yadav N, Thakur S, Sudhakar K, Rosenholm JM. Solid lipid nanoparticles: Emerging colloidal nano drug delivery systems. Pharmaceutics. 2018; 10(4): 1-21. [CrossRef]

[49] Tekade RK, Maheshwari R, Tekade M, Chougule MB. Solid lipid nanoparticles for targeting and delivery of drugs and genes. In: Nanotechnology-Based Approaches for Targeting and Delivery of Drugs and Genes. 2017: 256-286. [CrossRef]

[50] Almeida AJ, Souto E. Solid lipid nanoparticles as a drug delivery system for peptides and proteins. Adv Drug Deliv Rev. 2007; 59(6): 478-490. [CrossRef]

[51] Moritz M, Geszke-Moritz M. Recent developments in the application of polymeric nanoparticles as drug carriers. Adv Clin Exp Med. 2015; 24(5): 749-58. [CrossRef]

[52] Bennet D, Kim S. Polymer nanoparticles for smart drug delivery. Sezer AD (Editor). In: Application of Nanotechnology in Drug Delivery. 2014: 257-310. [CrossRef]

[53] Lou B, De Beuckelaer A, Boonstra E, Li D, De Geest BG, De Koker S, Mastrobattista E, Hennink WE. Modular coreshell polymeric nanoparticles mimicking viral structures for vaccination. J Control Release. 2019; 293: 48-62. [CrossRef]

[54] Kumari A, Yadav SK, Yadav SC. Biodegradable polymeric nanoparticles based drug delivery systems. Colloids Surf B: Biointerfaces. 2010; 75(1): 1-18. [CrossRef]

[55] Ye Y, Yu J, Wen D, Kahkoska AR, Gu Z. Polymeric microneedles for transdermal protein delivery. Adv Drug Deliv Rev. 2018; 127: 106-118. [CrossRef]

[56] Lee KY, Yuk SH. Polymeric protein delivery systems. Prog Polym Sci. 2007; 32(7): 669-697. [CrossRef]

[57] Castellanos IJ, Crespo R, Griebenow K. Poly (ethylene glycol) as stabilizer and emulsifying agent: a novel stabilization approach preventing aggregation and inactivation of proteins upon encapsulation in bioerodible polyester microspheres. J Control Release. 2003; 88(1): 135-145. [CrossRef]

[58] Li JK, Wang N, Wu XS. Poly (vinyl alcohol) nanoparticles prepared by freezing-thawing process for protein/peptide drug delivery. J Control Release. 1998; 56(1-3): 117-126. [CrossRef]

[59] Xu W, Ling P, Zhang T. Polymeric micelles, a promising drug delivery system to enhance bioavailability of poorly water-soluble drugs. J Drug Deliv. 2013; 2013: 340315. [CrossRef]

[60] Awasthi R, Bhushan B, Kulkarni GT. Concepts of nanotechnology in nanomedicine: From discovery to applications. In: Targeting Chronic Inflammatory Lung Diseases Using Advanced Drug Delivery Systems. Dua K, Hansbro P, Wadhwa R, Haghi M, Pont L, Williams K, Ed.; Elsevier Science B. V: Amsterdam, 2020; Vol. 1. [CrossRef]

[61] Ahmad Z, Shah A, Siddiq M, Kraatz HB. Polymeric micelles as drug delivery vehicles. RSC Adv. 2014; 4(33): 1702838. [CrossRef]

[62] Demeule M, Regina A, Che C, Poirier J, Nguyen T, Gabathuler R, Castaigne JP, Beliveau R. Identification and design of peptides as a new drug delivery system for the brain. J Pharmacol Exp Ther. 2008; 324(3): 1064-1072. [CrossRef]

[63] Batrakova EV, Bronich TK, Vetro JA, Kabanov AV. Polymer micelles as drug carrier. In: Torchilin VP (editor). Nanoparticulates as Drug Carriers. Imperial College Press, London. 2006; pp. 57-94.

[64] Kwon GS, Kataoka K. Block copolymer micelles as long-circulating drug vehicles. Adv Drug Deliv Rev. 1995; 16(23): 295-309. [CrossRef]

[65] Medeiros-Neves B, Nemitz MC, Silveira Fachel FN, Teixeira HF. Recent patents concerning the use of nanotechnology-based delivery systems as skin penetration enhancers. Recent Pat Drug Deliv Formul. 2019; 13(3): 192-202. [CrossRef]

[66] Livney YD. Potato protein nanoparticles. United States Patent US20160220502A1. August 4, 2016.

[67] Aimi M, Nemori R, Miyashita Y, Yokoyama H. Enzymatically crosslinked protein nanoparticles. WO2007086613A1. August 2, 2007.

[68] Rotello VM, Mout R, Nanoparticle-protein complex for intracellular protein delivery. United States Patent US 15/547,404. January 25, 2018. 
[69] Jianwu Z, Da L, Pingfan R. Paclitaxel-loaded semen armeniacae amarae protein nanocarrier and preparation method thereof. CN109956995. July 02, 2019.

[70] Wonjae Lee, Ha Ho-Kyung, Jinwook Kim, Seung Minkim, Kyoung Sikhan. Hydrogel nano carrier derived from goat milk protein resolvent and manufacturing method thereof. KR1018250290000*. March 14, 2018

[71] Kun H. Zein/ protein-polysaccharide electrostatic complex core/shell type nanocarrier as well as preparation method and application thereof. CN106692978A. February 14, 2020.

[72] Bookbinder L. Targeted prdm gene or protein modulation therapeutic agents. WO2011050178A3. September 22, 2011.

[73] Ventola CL. Progress in nanomedicine: approved and investigational nanodrugs. Pharmacy and Therapeutics. 2017; 42(12): 742-755.

[74] Zhong H, Chan G, Hu Y, Hu H, Ouyang D. A comprehensive map of FDA-approved pharmaceutical products. Pharmaceutics. 2018; 10(4): 1-19. [CrossRef]

[75] Yun Y, Cho YW, Park K. Nanoparticles for oral delivery: targeted nanoparticles with peptidic ligands for oral protein delivery. Adv Drug Deliv Rev. 2013; 65(6): 822-32. [CrossRef]

[76] Pisal DS, Kosloski MP, Balu-Iyer SV. Delivery of therapeutic proteins. J Pharm Sci. 2010; 99(6): 2557-2575. [CrossRef]

[77] Fosgerau K, Hoffmann T. Peptide therapeutics: current status and future directions. Drug Discov Today. 2015; 20(1): 122-128. [CrossRef]

[78] Niu Z, Conejos-Sánchez I, Griffin BT, O’Driscoll CM, Alonso MJ. Lipid-based nanocarriers for oral peptide delivery. Adv Drug Deliv Rev. 2016; 106: 337-354. [CrossRef]

[79] Ma B, Niu F, Qu X, He W, Feng C, Wang S, Ouyang Z, Yan J, Wen Y, Xu D, Shao Y. A tetrameric protein scaffold as a nano-carrier of antitumor peptides for cancer therapy. Biomaterials. 2019; 1-12. [CrossRef]

[80] Baker ME. Albumin's role in steroid hormone action and the origins of vertebrates: is albumin an essential protein? FEBS Lett. 1998; 439: 9-12. [CrossRef]

[81] Debelle L, Tamburro AM. Elastin: molecular description and function. Int J Biochem Cell Biol. 1999; 31: $261-272$. [CrossRef]

[82] Gupta AK, Berry CC, Gupta M, Curtis A. Receptor-mediated targeting of magnetic nanoparticles using insulin as a surface ligand to prevent endocytosis, IEEE Trans. Nanobioscience. 2003; 2: 255-261. [CrossRef]

[83] Mo Y, Lim LY. Paclitaxel-loaded PLGA nanoparticles: potentiation of anticancer activity by surface conjugation with wheat germ agglutinin. J Control Release. 2005; 108(2-3): 244-262. [CrossRef]

[84] Gref R, Couvreur P, Barratt G, Mysiakine E. Surface-engineered nanoparticles for multiple ligand coupling. Biomaterials. 2003; 24(24): 4529-4537. [CrossRef]

[85] Gao X, Wang T, Wu B, Chen J, Chen J, Yue Y, Dai N, Chen H, Jiang X. Quantum dots for tracking cellular transport of lectin-functionalized nanoparticles. Biochem Biophys Res Commun. 2008; 377(1): 35-40. [CrossRef]

[86] Weissenböck A, Wirth M, Gabor F. WGA-grafted PLGA-nanospheres: preparation and association with Caco-2 single cells. J Control Rel. 2004; 99(3): 383-392. [CrossRef]

[87] Mo Y, Lim LY. Preparation and in vitro anticancer activity of wheat germ agglutinin (WGA)-conjugated PLGA nanoparticles loaded with paclitaxel and isopropyl myristate. J Control Rel. 2005; 107(1): 30-42. [CrossRef]

[88] Yin Y, Chen D, Qiao M, Wei X, Hu H. Lectin-conjugated PLGA nanoparticles loaded with thymopentin: ex vivo bioadhesion and in vivo biodistribution. J Control Rel. 2007; 123(1): 27-38. [CrossRef]

[89] Jeong YI, Seo SJ, Park IK, Lee HC, Kang IC, Akaike T, Cho CS. Cellular recognition of paclitaxel-loaded polymeric nanoparticles composed of poly ( $\gamma$-benzyl L-glutamate) and poly (ethylene glycol) diblock copolymer endcapped with galactose moiety. Int J Pharm. 2005; 296(1-2): 151-161. [CrossRef]

[90] Bellis SL. Advantages of RGD peptides for directing cell association with biomaterials. Biomaterials. 2011; 32(18): 4205-4210. [CrossRef]

[91] Ruoslahti E. RGD and other recognition sequences for integrins. Annu Rev Cell Dev Biol. 1996; 12(1): 697-715. [CrossRef]

[92] Hersel U, Dahmen C, Kessler H. RGD modified polymers: biomaterials for stimulated cell adhesion and beyond. Biomaterials. 2003; 24(24): 4385-4415. [CrossRef] 
[93] Andersson M, Fromell K, Gullberg E, Artursson P, Caldwell KD. Characterization of surface-modified nanoparticles for in vivo biointeraction. A sedimentation field flow fractionation study. Anal Chem. 2005; 77(17): 5488-5493. [CrossRef]

[94] Montet X, Funovics M, Montet-Abou K, Weissleder R, Josephson L. Multivalent effects of RGD peptides obtained by nanoparticle display. J Med Chem. 2006; 49(20): 6087-6093. [CrossRef]

[95] Qian ZM, Li H, Sun H, Ho K. Targeted drug delivery via the transferrin receptor-mediated endocytosis pathway. Pharmacol Rev. 2002; 54(4): 561-587. [CrossRef]

[96] Wagner E, Curiel D, Cotten M. Delivery of drugs, proteins and genes into cells using transferrin as a ligand for receptor-mediated endocytosis. Adv Drug Deliv Rev. 1994; 14(1): 113-135. [CrossRef]

[97] Daniels TR, Delgado T, Helguera G, Penichet ML. The transferrin receptor part II: targeted delivery of therapeutic agents into cancer cells. Clin Immunol. 2006; 121(2): 159-176. [CrossRef]

[98] Berry CC, Charles S, Wells S, Dalby MJ, Curtis AS. The influence of transferrin stabilised magnetic nanoparticles on human dermal fibroblasts in culture. Int J Pharm. 2004; 269(1): 211-25. [CrossRef]

[99] Daniels TR, Delgado T, Rodriguez JA, Helguera G, Penichet ML. The transferrin receptor part I: Biology and targeting with cytotoxic antibodies for the treatment of cancer. Clin Immunol. 2006; 121(2): 144-158. [CrossRef]

[100] Franks SJ, Firipis K, Ferreira R, Hannan KM, Williams RJ, Hannan RD, Nisbet DR. Harnessing the self-assembly of peptides for the targeted delivery of anti-cancer agents. Mater Horiz. 2020; 7: 1996-2010. [CrossRef]

[101] Qin Y, Qin ZD, Chen J, Cai CG, Li L, Feng LY, Wang Z, Duns GJ, He NY, Chen ZS, Luo XF. From antimicrobial to anticancer peptides: the transformation of peptides. Recent Pat Anticancer Drug Discov. 2019; 14(1): 70-84. [CrossRef]

[102] Battaglia L, Ugazio E. Lipid nano-and microparticles: an overview of patent-related research. J Nanomater. 2019; 2019. [CrossRef]

This is an open access article which is publicly available on our journal's website under Institutional Repository at http://dspace.marmara.edu.tr. 